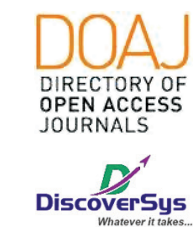

Published by DiscoverSys

\section{Tingkat pengetahuan dan sikap tentang hepatitis B pada dokter gigi di Denpasar Utara}

\author{
I Gusti Ngurah Bagus Jayanta Ananda ${ }^{1{ }^{*}}$ I Ketut Agus Somia ${ }^{2}$
}

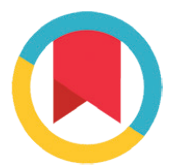

CrossMark

\title{
ABSTRACT
}

Introduction: Hepatitis B virus is a double stranded DNA virus that belongs to hepadnaviridae family. This virus can be transmitted through unsterile medical instruments, unsafe sex, and blood transfusions from hepatitis B infected individuals. This study aims to evaluate the knowledge and attitude of hepatitis $B$ among dentist in North Denpasar. Method: This study was a descriptive cross sectional study. Data collection was done by using questionnaire. The study population were dentists in North Denpasar. Subject consisted of 28 respondents that were chosen by random sampling. Study was done from November 2016 until January 2017.

Result: Majority of the respondent had a high knowledge level (75\%) regarding transmission of hepatitis B. Similar proportion was found for high and low knowledge level regarding prevention of hepatitis $B$. Most respondent (57.8\%) had a low level of knowledge regarding hepatitis $B$ in general. More respondent had a positive attitude regarding hepatitis $B(71.4 \%)$. Majority of respondent aged $<30$ years old had a good knowledge (64.2\%), meanwhile bad knowledge was found in more respondent for other age group. Based on the characteristic of attitude regarding hepatitis $B$ according to age and gender, it was found that more respondent had a positive attitude in each group.

Conclusion: Results of this study found that most of the respondent had a good knowledge and attitude regarding hepatitis $B$, but the knowledge in respondent aged over 30 were found to be bad.
'Program Studi Pendidikan Dokter, Fakultas Kedokteran Universitas Udayana

${ }^{2}$ Departemen IImu Penyakit Dalam, Fakultas Kedokteran, Universtas Udayana-RSUP Sanglah Denpasar, Bali-Indonesia
*Correspondece to:

I Gusti Ngurah Bagus Jayanta Ananda, Program Studi Pendidikan Dokter, Fakultas Kedokteran Universitas Udayana

ananda.jayanta@gmail.com
Diterima: 17-06-2019

Disetujui: 03-01-2020

Diterbitkan: 03-03-2020

Keywords: Hepatitis B, knowledge, attitude, dentist

Cite this Article: Ananda, I.G.N.B.J., Somia, I.K.A. 2020. Tingkat pengetahuan dan sikap tentang hepatitis B pada dokter gigi di Denpasar Utara. Intisari Sains Medis 11(1): 51-54. D0I: 10.15562/ism.v11i1.530

\section{ABSTRAK}

Pendahuluan: Virus hepatitis B merupakan virus DNA beruntai ganda yang termasuk dalam famili hepadnaviridae. Penularan hepatitis B terjadi melalui alat medis tidak steril, hubungan seksual berisiko, dan transfusi darah dari individu yang terinfeksi virus hepatitis $B$. Penelitian ini dilakukan untuk mengetahui tingkat pengetahuan dan sikap mengenai hepatitis B pada dokter gigi di Denpasar Utara.

Metode: Penelitian ini merupakan studi deskriptif cross-sectional dengan metode pengumpulan data melalui kuisioner. Subjek penelitian adalah dokter gigi di Denpasar Utara. Sejumlah 28 sampel dipilih dengan teknik random sampling yang dilaksanakan dari November 2016 hingga Januari 2017.

Hasil: Mayoritas subjek memiliki tingkat pengetahuan yang tinggi (75\%) mengenai penyebaran hepatitis B. Proporsi yang sama didapatkan untuk tingkat pengetahuan tinggi dan rendah mengenai pencegahan hepatitis B. Mayoritas subjek (57,8\%) memiliki tingkat pengetahuan yang rendah tentang hepatitis $B$ secara umum. Lebih banyak responden didapatkan memiliki sikap positif terhadap hepatitis B (71,4\%). Sebagian besar responden berusia $<30$ tahun memiliki tingkat pengetahuan yang baik $(64,2 \%)$, sedangkan tingkat pengetahuan buruk lebih banyak didapatkan pada kedua kelompok usia lainnya. Berdasarkan karakteristik sikap dokter gigi terhadap hepatitis sesuai umur maupun sesuai jenis kelamin, pada tiap kelompoknya didapatkan lebih banyak responden yang memiliki sikap positif.

Simpulan: Hasil penelitian menunjukkan bahwa tingkat pengetahuan dan sikap tentang hepatitis B pada dokter gigi di Denpasar Utara sebagian besar adalah baik, namun pada kelompok usia diatas 30 tahun, tingkat pengetahuan terkait hepatitis $B$ adalah kurang baik.

Kata kunci: Hepatitis B, pengetahuan, sikap, dokter gigi

Cite Pasal Ini:Ananda, I.G.N.B.J., Somia, I.K.A. 2020. Tingkat pengetahuan dan sikap tentang hepatitis B pada dokter gigi di Denpasar Utara. Intisari Sains Medis 11(1): 51-54. D0I: 10.15562/ism.v11i1.530

\section{PENDAHULUAN}

Virus hepatitis B merupakan virus DNA beruntai ganda yang termasuk dalam famili hepadnaviradae. Virus hepatitis B menular melalui alat medis yang tidak steril, hubungan seksual berisiko, dan transfusi darah dari individu yang terinfeksi virus hepatitis B. Virus ini dapat bertahan di luar tubuh selama setidaknya 7 hari dengan periode inkubasi selama 21-135 hari. $^{1}$ 
Sepertiga dari seluruh penduduk dunia diperkirakan telah terinfeksi oleh virus hepatitis B dan sekitar 400 juta orang merupakan pengidap kronik hepatitis B. Prevalens di Indonesia dilaporkan berkisar antara 3-17\%. ${ }^{2}$ Sebanyak lebih dari 2 milyar orang diperkirakan telah terinfeksi oleh virus hepatitis B selama kehidupan mereka. Tujuh puluh lima persen dari seluruh pembawa kronis tinggal di Asia dan pesisir Pasifik Barat. ${ }^{3}$ Data yang didapat dari Center For Disease Control and Prevention (CDC) menunjukkan bahwa sejumlah 200.000 hingga 300.000 orang, khususnya populasi dewasa muda terinfeksi oleh virus hepatitis B tiap tahunnya. Sekitar 10.000 kasus hepatitis B memerlukan perawatan rumah sakit, dan sekitar 1-2\% meninggal karena penyakit fulminan. ${ }^{4}$ Prevalens pengidap hepatitis B didapatkan tertinggi di Afrika dan Asia. Hasil Riset Kesehatan Dasar (Riskesdas) tahun 2007 menunjukan bahwa hepatitis klinis terdeteksi di seluruh Indonesia dengan prevalens sebesar 0,6\% (rentang 0,2\%-1,9\%). Riskesdas tahun 2007 menunjukan bahwa persentase individu dengan HbsAg positif adalah sebesar 9,4\%. Persentase hepatitis B didapatkan tertinggi pada kelompok usia 45 - 49 tahun (11,29\%), sedangkan pada usia $>60$ tahun adalah sebesar 10,57\% dan usia 10 - 14 tahun adalah sebesar $10,02 \%$. Temuan HbsAg positif pada kelompak laki-laki dan perempuan adalah hampir sama yaitu sebesar 9,7\% dan 9,3\% berturut-turut. Hal ini menunjukan bahwa 1 dari 10 penduduk Indonesia terinfeksi virus hepatitis B. ${ }^{5}$

Petugas kesehatan yang mengalami paparan langsung terhadap berbagai faktor resiko, sangatlah rentan untuk terinfeksi virus ini. Salah satunya adalah penularan virus dari pasien poli gigi terhadap dokter gigi, maupun sebaliknya. Salah satu hal yang dapat berpengaruh terhadap angka penularan dan morbiditas serta mortalitas akibat virus hepatitis B pada petugas kesehatan terutama antara dokter gigi dan pasiennya adalah tingkat pengetahuan dan sikap terkait masalah tersebut.

Penelitian ini dilakukan untuk memberikan gambaran umum mengenai tingkat pengetahuan

\section{Tabel 1 Karakteristik Umum Sampel}

\begin{tabular}{lcc}
\hline Variabel & Jumlah (N) & Persentase (\%) \\
\hline Jenis Kelamin & 7 & \\
$\quad$ Laki Laki & 21 & $25 \%$ \\
$\quad$ Perempuan & & $75 \%$ \\
Umur & 14 & \\
$\quad<30$ tahun & 7 & $50 \%$ \\
tahun & 7 & $25 \%$ \\
$>40$ tahun & & $25 \%$ \\
\hline
\end{tabular}

dan sikap dokter gigi di daerah Denpasar Utara terkait hepatitis B, melalui studi berbasis kuesioner.

\section{METODE}

Penelitian berupa studi observasional jenis deskriptif, dirancang dalam bentuk studi potong lintang (cross-sectional) untuk mengetahui tingkat pengetahuan dan sikap mengenai hepatitis B pada dokter gigi yang ada di Denpasar Utara.

Sampel penelitian adalah 28 dokter gigi yang berpraktek di Denpasar Utara. Penelitian dilakukan dengan pengisian kuisioner setelah informed consent. Sampel diminta untuk menjawab pertanyaan yang diberikan berdasarkan petunjuk yang disediakan. Tingkat pengetahuan dan sikap dokter gigi tentang hepatitis B selanjutnya dievaluasi berdasarkan skoring yang diperoleh.

Pengolahan data dilakukan dalam beberapa tahapan, yang meliputi tahap editing yaitu memastikan data identitas, data responden lainnya serta seluruh jawaban diisi sesuai petunjuk yang diberikan, tahap coding yaitu memberi kode spesifik pada kuesioner sehingga peneliti dapat lebih mudah melakukan tabulasi dan analisa data, tahap entry yaitu menginput data dari kuisioner yang telah diisi ke dalam program komputer, pada penelitian ini digunakan program SPSS (Statistical Product and Service Solution), tahap cleaning yaitu memastikan kembali tidak ada kesalahan dalam data yang telah di entry. Data yang telah terkumpul kemudian ditabulasi dalam bentuk tabel untuk mendeskripsikan data dalam angka absolut dan persentase sesuai tujuan penelitian.

Penelitian ini telah disetujui oleh Komisi Etik Penelitian Kesehatan Fakultas Kedokteran Universitas Udayana/RSUP Sanglah Denpasar, Bali.

\section{HASIL}

Terdapat total 28 jumlah subjek dengan rincian $7(25 \%)$ orang laki laki dan $21(75 \%)$. orang perempuan. Berdasarkan karakteristik usia, sebanyak 14 orang responden (50\%) berusia kurang dari 30 tahun, 7 orang responden (25\%) berusia 31-40 tahun sedangkan 7 orang responden (25\%) berusia di atas 40 tahun. Karakteristik umum sampel tertera pada Tabel 1.

Berdasarkan karakteristik tingkat pengetahuan tentang penyebaran hepatitis $\mathrm{B}$, dapat diketahui bahwa 21 orang responden $(75 \%)$ memiliki tingkat pengetahuan yang tinggi atau di atas angka rerata, sedangkan 7 orang responden (25\%) memiliki tingkat pengetahuan yang rendah atau di bawah angka rerata. Berdasarkan karakteristik tingkat pengetahuan tentang pencegahan hepatitis $\mathrm{B}$, dapat 
Tabel 2 Gambaran Tingkat Pengetahuan Tentang Hepatitis B pada Dokter Gigi di Denpasar Utara

\begin{tabular}{lcc}
\hline Variabel & Jumlah (N) & Persentase (\%) \\
\hline $\begin{array}{l}\text { Tingkat pengetahuan tentang penyebaran } \\
\text { Tinggi }\end{array}$ & 21 & $75 \%$ \\
$\quad$ Rendah & 7 & $25 \%$ \\
Tingkat pengetahuan tentang pencegahan & & \\
Tinggi & 14 & $50 \%$ \\
$\quad$ Rendah & 14 & $50 \%$ \\
Tingkat Pengetahuan Tentang Hepatitis B & & \\
$\quad$ Tinggi & 12 & $42,8 \%$ \\
$\quad$ Rendah & 16 & $57,2 \%$ \\
\hline
\end{tabular}

Tabel 3 Gambaran Sikap Dokter Gigi di Denpasar Utara Tentang Hepatitis B

\begin{tabular}{lcc}
\hline Variabel & Jumlah (N) & Persentase (\%) \\
\hline Sikap & & \\
Positif & 20 & $71,4 \%$ \\
Negatif & 8 & $28,6 \%$ \\
\hline
\end{tabular}

Tabel 4 Tabulasi Silang Tingkat Pengetahuan Berdasarkan Umur Responden

\begin{tabular}{|c|c|c|c|c|}
\hline \multirow[b]{3}{*}{ Variabel } & \multicolumn{4}{|c|}{ Tingkat Pengetahuan } \\
\hline & \multicolumn{2}{|c|}{ Baik } & \multicolumn{2}{|c|}{ Buruk } \\
\hline & $\mathbf{N}$ & $\%$ & $\mathbf{N}$ & $\%$ \\
\hline \multicolumn{5}{|l|}{ Umur } \\
\hline$<30$ tahun & 9 & $64,2 \%$ & 5 & $35,8 \%$ \\
\hline 31-40 tahun & 3 & $42,8 \%$ & 4 & $57,2 \%$ \\
\hline$>41$ tahun & 1 & $14,2 \%$ & 6 & $85,8 \%$ \\
\hline
\end{tabular}

Tabel 5 Tabulasi Silang Tingkat Pengetahuan Berdasarkan Jenis Kelamin Responden

\begin{tabular}{|c|c|c|c|c|}
\hline \multirow[b]{3}{*}{ Variabel } & \multicolumn{4}{|c|}{ Tingkat Pengetahuan } \\
\hline & \multicolumn{2}{|c|}{ Baik } & \multicolumn{2}{|c|}{ Buruk } \\
\hline & $\mathbf{N}$ & $\%$ & $\mathbf{N}$ & $\%$ \\
\hline \multicolumn{5}{|l|}{ Jenis Kelamin } \\
\hline Laki-Laki & 3 & $42,8 \%$ & 4 & $57,2 \%$ \\
\hline Perempuan & 10 & $47,6 \%$ & 11 & $52,4 \%$ \\
\hline
\end{tabular}

diketahui bahwa terdapat masing-masing 14 orang responden $(50 \%)$ yang memiliki tingkat pengetahuan yang tinggi dan rendah. Secara umum, 12 responden $(42,8 \%)$ memiliki tingkat pengetahuan yang tinggi tentang hepatitis $\mathrm{B}$, sementara $16(57,8 \%)$ lainnya memiliki tingkat pengetahuan yang rendah. Gambaran tingkat pengetahuan tentang hepatitis B pada dokter gigi di Denpasar Utara tertera pada tabel 2.
Berdasarkan sikap tentang hepatitis B, 20 orang responden $(71,4 \%)$ memiliki sikap positif dan 8 orang responden $(28,6 \%)$ memiliki sikap negatif tehadap hepatits B. Gambaran sikap dokter gigi di Denpasar Utara tentang hepatitis B tertera pada Tabel 3.

Berdasarkan karakteristik tingkat pengetahuan sesuai usia, didapatkan 9 orang responden $(64,2 \%)$ dengan usia di bawah 30 tahun memiliki tingkat pengetahuan yang baik, sedangkan 5 orang responden $(35,8 \%)$ memiliki tingkat pengetahuan yang buruk mengenai hepatitis B. Sebanyak 3 orang responden $(42,8 \%)$ pada kelompok usia 31-40 tahun, memiliki tingkat pengetahuan yang baik, sedangkan 4 orang responden $(57,2 \%)$ memiliki tingkat pengetahuan yang buruk mengenai hepatitis B. Sebanyak 1 orang responden $(14,2 \%)$ pada kelompok usia 41 tahun keatas, memiliki tingkat pengetahuan yang baik, sedangkan 6 orang responden $(85,8 \%)$ memiliki tingkat pengetahuan yang buruk mengenai hepatitis B. Tingkat pengetahuan berdasarkan umur responden tertera pada Tabel 4 .

Berdasarkan karakteristik tingkat pengetahuan sesuai jenis kelamin, untuk jenis kelamin laki laki didapatkan 3 orang responden $(42,8 \%)$ memiliki tingkat pengetahuan yang baik, sedangkan 4 orang responden $(57,2 \%)$ memiliki tingkat pengetahuan yang buruk tentang hepatitis B. Sebanyak 10 orang responden $(47,6 \%)$ pada kelompok perempuan memiliki tingkat pengetahuan yang baik, sedangkan 11 orang responden $(52,4 \%)$ memiliki tingkat pengetahuan yang buruk tentang hepatitis $B$. Tingkat pengetahuan berdasarkan jenis kelamin tertera pada Tabel 5 .

Berdasarkan karakteristik sikap dokter gigi terhadap hepatitis sesuai umur, didapatkan bahwa dokter gigi yang berumur kurang dari 30 tahun, yaitu sebanyak 9 responden $(64,2 \%)$ memiliki sikap positif terhadap hepatitis B, sedangkan 5 orang responden $(35,8 \%)$ memiliki sikap negatif terhadap hepatitis B. Seluruh responden yaitu sebanyak 7 orang (100\%) memiliki sikap positif terhadap hepatitis B pada kelompok usia 31-40 tahun, pada kelompok usia di atas 41 tahun sebanyak 4 responden $(57,1 \%)$ memiliki sikap positif terhadap hepatitis B sedangkan sebanyak 3 orang responden $(42,9 \%)$ memiliki sikap negatif terhadap hepatitis B. Gambaran sikap dokter gigi berdasarkan umur terhadap hepatitis B tertera pada Tabel 6 .

Berdasarkan gambaran sikap dokter gigi terhadap hepatitis B sesuai jenis kelamin, untuk jenis kelamin laki-laki, sebanyak 5 orang responden $(71,4 \%)$ memiliki sikap positif sedangkan 2 orang responden $(28,6 \%)$ memiliki sikap negatif terhadap hepatitis B. Sebanyak 15 orang responden $(71,4 \%)$ pada kelompok perempuan memiliki sikap positif, sedangkan 6 orang responden $(28,6 \%)$ memiliki 
Tabel 6 Tabulasi Silang Gambaran Sikap Dokter Gigi berdasarkan Umur terhadap Hepatitis B

\begin{tabular}{|c|c|c|c|c|}
\hline \multirow[b]{3}{*}{ Variabel } & \multicolumn{4}{|c|}{ Sikap } \\
\hline & \multicolumn{2}{|c|}{ Positif } & \multicolumn{2}{|c|}{ Negatif } \\
\hline & $\mathbf{N}$ & $\%$ & $\mathbf{N}$ & $\%$ \\
\hline \multicolumn{5}{|l|}{ Umur } \\
\hline$<30$ tahun & 9 & $64,2 \%$ & 5 & $35,8 \%$ \\
\hline tahun & 7 & $100 \%$ & 0 & $0 \%$ \\
\hline$>41$ tahun & 4 & $57,1 \%$ & 3 & $42,9 \%$ \\
\hline
\end{tabular}

Tabel 7 Tabulasi Silang Gambaran Sikap Dokter Gigi berdasarkan Jenis Kelamin terhadap Hepatitis B

\begin{tabular}{lccccc}
\hline & \multicolumn{5}{c}{ Sikap } \\
\cline { 2 - 3 } \cline { 5 - 6 } Variabel & $\mathbf{N}$ & $\%$ & & $\mathbf{N}$ & Negatif \\
\hline Jenis Kelamin & & & & \\
$\quad$ Laki-Laki & 5 & $71,4 \%$ & & 2 & $28,6 \%$ \\
Perempuan & 15 & $71,4 \%$ & & 6 & $28,6 \%$ \\
\hline
\end{tabular}

sikap negatif terhadap hepatitis B. Gambaran sikap dokter gigi berdasarkan jenis kelamin terhadap hepatitis B tertera pada Tabel 7.

\section{PEMBAHASAN}

Jenis kelamin perempuan dan kelompok usia $<30$ tahun mendominasi sampel dari penelitian ini. Mayoritas subjek memiliki tingkat pengetahuan tinggi yaitu sebesar $75 \%$, dan hanya $25 \%$ yang memiliki tingkat pengetahuan rendah mengenai cara penyebaran virus hepatitis B. Proporsi subjek dengan tingkat pengetahuan tinggi dan rendah terkait pencegahan hepatitis $\mathrm{B}$ adalah sama. Mayoritas subjek memiliki tingkat pengetahuan mengenai hepatitis B secara umum yang rendah yaitu sebesar $57,2 \%$. Hasil ini berbeda dengan penelitian yang dilakukan oleh Sowmya K, dkk., (2013) yang menunjukan bahwa $82,15 \%$ responden memiliki pengetahuan yang baik tentang hepatitis B dan juga penyebarannya. ${ }^{6}$ Hal ini dapat disebabkan oleh kurangnya sosialisasi mengenai hepatitis B pada dokter gigi.

Penelitian ini menunjukkan bahwa sebagian besar subjek memiliki sikap terhadap hepatitis B yang positif, dengan persentase $71,4 \%$. Temuan ini sejalan dengan temuan Tirounilacandin P dkk., dimana mayoritas dokter gigi memiliki sikap baik terhadap hepatitis B. ${ }^{7,8}$

Tingkat pengetahuan yang baik didominasi oleh dokter gigi yang berada pada kelompok usia <30 tahun, sedangkan pada kelompok usia 31-40 dan $>40$ tahun sebagian besar memiliki tingkat pengetahuan yang buruk mengenai hepatitis
B. Hasil penelitian terkait tingkat pengetahuan berdasarkan jenis kelamin, didapatkan dominasi responden dengan tingkat pengetahuan yang buruk, baik pada kelompok laki-laki dan perempuan.

\section{SIMPULAN}

Berdasarkan hasil penelitian ini diperoleh kesimpulan bahwa tingkat pengetahuan dan sikap tentang hepatitis B pada dokter gigi di Denpasar Utara sebagian besar adalah baik, namun pada kelompok usia diatas 30 tahun, tingkat pengetahuan terkait hepatitis B adalah kurang baik.

\section{KONFLIK KEPENTINGAN}

Penulis menyatakan tidak terdapat konflik kepentingan terkait publikasi dari artikel ini.

\section{PENDANAAN}

Penelitian ini tidak mendapatkan pendanaan dari pemerintah ataupun sektor swasta lainnya

\section{ETIKA DALAM PENELITIAN}

Penelitian ini telah mendapatkan persetujuan dari Komite Etik Fakultas Kedokteran Universitas Udayana/RSUP Sanglah Denpasar dengan nomer referensi 130/UN.14.2/KEP/2017.

\section{DAFTAR PUSTAKA}

1. Sharma SK, Saini N, Chwla Y. Hepatitis B virus: inactive carriers. Virology Journal. 2005; 2:82-90.

2. Soewignjo S, Gunawan S. Hepatitis virus B. EGC. 2008: 250-261.

3. Kumar V, Cotran RS, Robbins SL. Buku Ajar Patologi Robbins. EGC. 2012:136-139.

4. Price SA, Wilson LM. Patofisiologi: Konsep Klinis. ProsesProses Penyakit. 2012. EGC: 53-62.

5. Badan Penelitian dan Pengembangan Kesehatan Kementerian Kesehatan RI. Riset Kesehatan Dasar 2013. 2013.

6. Sowmya K, Anubhuti M, Dhara D, Manisha T, Shreenivas K, Sandeep G. A cross sectional study on the knowledge of hepatitis $\mathrm{B}$ infection among dental professionals. Journal of Virology and Microbiology. 2013; 4(2):45-52.

7. Tirounilacandin P, Krishnaraj S, Chakravarthy K. Hepatitis-B infection: awareness among medical, dental interns in India. Ann Trop Med Public Health. 2009; 2: 33-36.

8. Khan S. Detection of hepatitis B virus in clinically suspected infectious hepatitis pregnant and non-pregnant women. Bali Medical Journal. 2017; 6(3): S105-S108. DOI: 10.15562/bmj.v6i3.366

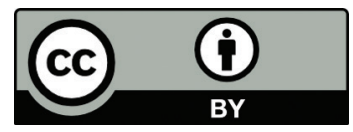

This work is licensed under a Creative Commons Attribution 